\title{
The Role of HOXGenes as Potential Biomarkers in Colorectal Cancer: A Systematic Review
}

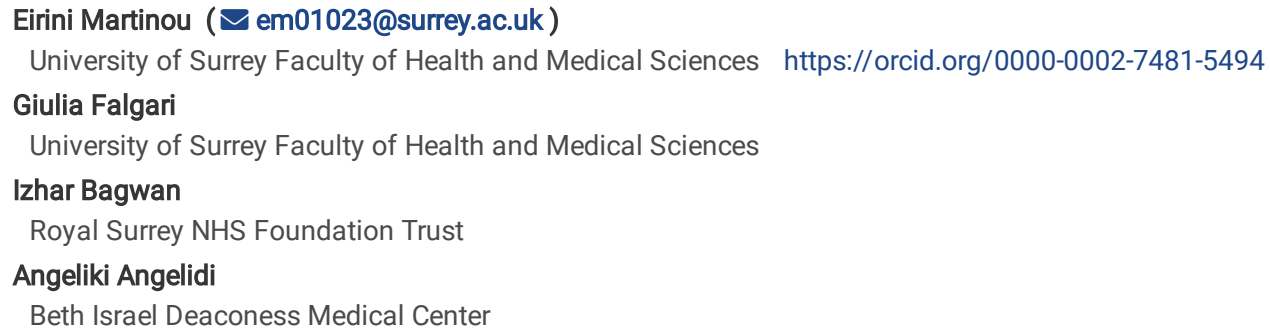

\section{Research article}

Keywords: Homeobox, HOX, colorectal, cancer, adenocarcinoma

Posted Date: November 4th, 2021

DOI: https://doi.org/10.21203/rs.3.rs-618476/v4

License: (c) (i) This work is licensed under a Creative Commons Attribution 4.0 International License. Read Full License 


\section{Abstract}

Background: Colorectal cancer (CRC) is worldwide the third leading cause of cancer-related death, and despite therapeutic advances, survival remains low. Emerging evidence shows that Homeobox (HOX) genes are important in carcinogenesis, and their dysregulation has been linked with metastatic potential and poor prognosis. This systematic review aims to present the current evidence on the role of HOX genes as biomarkers in CRC and the impact of their modulation in tumour growth and progression.

Methods: MEDLINE, EMBASE, Web of Science and Cochrane databases were searched by following the Preferred Reporting Items for Systematic Reviews and Meta-Analysis (PRISMA) statement. Eligible studies investigated two research questions: a) the clinicopathological and prognostic significance of $H O X$ gene dysregulation in patients with $\mathrm{CRC}$ and $\mathrm{b}$ ) the functional role of HOX genes in CRC progression. This study was registered in the international prospective register of systematic reviews (PROSPERO), CRD42020190953.

Results: Twenty-five studies enrolling 3003 patients with stage I-IV CRC, showed that 26 out of 39 HOX genes were dysregulated in cancerous versus normal colon. Aberrant expression of HOX proteins was significantly related to tumour depth, nodal invasion, distant metastases, advanced stage and poor prognosis. Twenty-two preclinical studies showed that HOX proteins are crucially related to tumour growth and metastatic potential by affecting cell proliferation and altering the expression of epithelial-mesenchymal transition modulators.

Conclusions: In conclusion, our findings suggest that HOX proteins play vital roles in CRC progression and significantly affect survival. Further research, though, is required to elucidate their potential role as biomarkers in CRC.

\section{Introduction}

Colorectal Cancer (CRC) is the most common gastrointestinal malignancy and the third worldwide leading cause of cancer-related death[1,2]. Despite significant advances in diagnostic and therapeutic strategies, the prognosis for CRC patients remains poor, indicating that cancerous cells are not entirely eradicated by current therapies, thus leading to metastatic disease which is the primary cause of cancer-related mortality[3]. CRC arises as a result of the accumulation of genetic and epigenetic changes, which transform normal glandular epithelial cells into invasive carcinomas and eventually progress into metastatic disease[4]. Colorectal carcinogenesis is a complex multistep process involving the dysregulation of oncogenes or tumour suppressor genes related to initiation, progression and resistance to therapy[4,5]. Therefore, there is an urgent need to identify novel biomarkers which could be used to predict prognosis and act as therapeutic targets.

Since the last decades, a lot of attention has been paid to the role of homeobox [HOX] genes in cancer[6]. HOX genes encode a highly conserved family of homeodomain-containing transcription factors which play essential roles in embryonic development including morphogenesis, organogenesis and differentiation[7]. HOX proteins control various cellular processes by regulating the expression of several downstream target genes; hence they can alter cell behaviour such as proliferation, invasion and migration[7]. The human genome contains 39 HOX genes which are classified into four clusters, $H O X A$, $H O X B$, $H O X C$ and $H O X D$ based on their sequence similarity and chromosomal position, [figure 1][8]. Dysregulation in HOX gene expression leads to developmental abnormalities and is associated with an increased incidence of malignant tumours in humans[9,10]. Emerging evidence shows that $H O X$ genes can act either as oncogenes or tumour suppressors depending on cancer type. For instance, HOXA9 has an oncogenic role in acute leukaemia[11] whereas it acts as a tumour suppressor in breast cancer by regulating the expression of Breast Cancer gene 1 (BRCA1)[12]. Additionally, HOXB9 has been shown to inhibit cancer cell proliferation in gastric carcinoma[13] whilst it demonstrates an oncogenic role in breast cancer[14].

Expression of HOX genes is dysregulated and often reported to be associated with adverse clinicopathological characteristics and poor survival in various types of cancers[15-17]. However, their differential expression and their role as potential biomarkers in CRC has not been fully explored. To better understand the existing evidence with regards to the prognostic and functional role of $H O X$ genes in CRC, the authors performed a systematic review of the current literature. Specifically, this review aims to answer the following research questions: a) What is the clinicopathological and prognostic significance of $H O X$ genes dysregulation in CRC and b) What is the functional role of HOX genes in CRC progression.

\section{Methods-materials}

\section{Search Strategy}

A literature search was conducted for eligible studies in the Medline, EMBASE, Web of Science and Cochrane Database search engines in accordance to the Preferred Reporting Items for Systematic Reviews and Meta-Analyses (PRISMA) guidelines[18]. The end date of the retrieval period was the $1^{\text {st }}$ of July. A search strategy was developed in Medline including keywords, MeSH (Medical Subject Headings) and synonyms related to HOX genes, colorectal and neoplasms. The strategy was adapted for the other databases using separate algorithms for each search engine (supplementary material, ESM_1). This systematic review was registered in the international prospective register of systematic reviews (PROSPERO) with identification number CRD42020190953.

\section{Eligibility criteria and study selection}

Three reviewers (EM, GF and AA) independently selected and identified eligible English language studies based on predefined inclusion criteria according to the research question. Discrepancies between the three reviewers were resolved by discussion or with a $4^{\text {th }}$ author. 
For the first research question, studies conducted on individuals over 18 years old with sporadic colorectal adenocarcinoma and reporting on $H O X$ genes were included. Specifically, studies reporting at least one of the following criteria were included: (i) studies on HOX dysregulation between cancer and normal tissue, (ii) studies on the association of HOX genes with clinicopathological characteristics of CRC, (iii) studies reporting outcome measures such as overall survival (OS) and disease-free survival (DFS). Exclusion criteria were studies reporting the dysregulation of HOX genes in cell lines (in vitro) or animal tissues (in vivo). Comparison groups were selected to be the following: cancer to normal colorectal tissue as well as high versus low HOX gene expression patient group. Outcomes were defined to be: HOX gene dysregulation, tumour depth, lymph node status, metastases, stage of colorectal cancer disease, grade of disease, disease-free survival (DFS) and overall survival (OS) rates.

For the second research question, laboratory-based and animal research studies were included reporting on the effect of $H O X$ gene expression in CRC cell growth. The intervention was considered gene expression editing to either suppress or overexpress the HOX gene of interest. The intervention group in the included studies consisted of either human colorectal cancer cell lines or animal models which had an altered expression of $H O X$ genes. Therefore, the comparison groups were defined as edited versus non-edited human CRC cell lines or animal models. Outcomes were selected to be cell proliferation, cell migration, cell invasion in vitro as well as tumour growth and metastases in vivo.

Studies such as case reports, editorials, opinions, conference abstracts, reviews and other secondary research studies were excluded. Studies not using the universal HOX chromosomal cluster terminology as described in figure 1 for reporting findings were also excluded for both research questions.

\section{Data Extraction, Synthesis and Quality Assessment}

For each study, the following details were extracted on publication year, surname of first author, study design, participant characteristics (sample size, gender), study characteristics (intervention and control group, endpoint assays) and outcomes. The quality of each eligible primary study involving human participants was assessed using the National Heart, Lung and Blood Institute (NIH) study quality assessment tools for case studies, available online https://www.nhlbi.nih.gov/health-topics/study-quality-assessment-tools, (table S1, ESM_2). Preclinical animal studies were assessed using the Systematic Review Centre for Laboratory animal experimentation risk of bias tool (SYRCLE'S), (table S2, ESM_3)[19,20]. For cell line studies, no established quality assessment tool is currently available[19]. The results were summarised narratively according to each research question using a qualitative data synthesis approach.

\section{Results}

\section{Study selection}

The initial literature search identified 2548 eligible citations. Following duplicate citation removal 1498 studies were screened for eligibility. For research question 1 and 2, a total of 25 and 22 studies met our inclusion criteria respectively and were included in the final analysis. The process of literature retrieval, according to PRISMA guidelines, is shown in detail in figure 2. Study characteristics and findings are presented for each research question separately.

\section{Clinicopathological and prognostic significance of HOX dysregulation in CRC}

\section{Study characteristics}

A total of 3003 patients with stage I-IV CRC between 20 and 90 years old were included in the studies[21-45] All 25 studies were single-centre and were published between 1997 and 2020. Two studies included patients who either received or not neoadjuvant chemotherapy[24,25], 5 studies included only patients without neoadjuvant chemotherapy $[23,26,27,29,42]$ whereas in the remaining studies no information on the chemotherapy status was available. Differential HOX gene expression between cancer and normal tissue was reported by 22 studies[21-23,25-28,30-34,36-45]. The analysis assays were realtime quantitative polymerase chain reaction [RT-qPCR], immunohistochemistry [IHC] or western blot [WB]. Four studies included bioinformatics analysis from publicly available RNA sequencing data[22,33,43,45], table 1 .

Seventeen studies investigated the association of HOX genes with clinicopathological characteristics in patients with CRC[21,23-33,35,40-42,44], table 1. Variables included at least one of the following: Age, sex, tumour depth, lymph node status, metastases, stage of colorectal cancer disease, grade of disease and carcinoembryonic antigen (CEA) levels.

The impact of HOX expression on OS and DFS in patients with CRC was investigated by $12[21-23,25,28-31,33,42-44]$ and $4[23,24,33,40]$ studies, respectively, table 1. OS and DFS rates in patients with high versus low expression of the HOX gene of interest were compared. Most of the studies used a semiquantitative IHC approach to score the expression levels of HOX proteins, whereas two studies used the median mRNA level as cut-off value[22,33].

\section{Findings}

\section{HOX dysregulation and clinicopathological significance in CRC}

Twenty-six out of $39 \mathrm{HOX}$ genes were identified in this systematic review to be differentially expressed in cancerous versus normal colon tissues with 15 of them being overexpressed and 6 being downregulated, (table 1). Discrepancies were reported between studies for 5 HOX genes (A4, B8, B9, B13 and D10) [26- 
30,33,36,37,41-43]. Among the dysregulated HOX genes and their protein products, several were found to demonstrate potential clinical significance in CRC. Three studies reported that patients with high $\operatorname{HOX}(B 7, B 9, C 6)$ protein expression levels demonstrated significantly advanced T status in comparison with patients with low expression, [24,25,31], (table 1). Similarly, regarding N status, 6 studies showed that the percentage of patients with regional lymph node invasion was significantly increased in the high HOX expression group for the following: HOXA3, A9, B8, B9, B13, C6, D1 and D9[21,25,30,32,41,44]. Inverse correlation between HOX expression and nodal invasion was demonstrated only for HOXD10 by Wang et al. [26](table 1). Eight studies investigated the presence of metastatic disease according to HOX expression levels[24,25,27-30,33,44]. Two studies by Liao et al.[31] and Huang et al.[30] for HOXB7 and B9 respectively, reported that significantly more patients had metastatic disease in the high HOX expression group in comparison with the low expression one, (table 1). Eleven studies have reported findings based on the overall stage of disease and level of HOX expression[21,23,27,29-31,33,35,40,42,44]. For HOXA3, $A 9, B 7$ and D9, high expression groups correlated with an increased number of patients with advanced disease in comparison with the low expression groups[21,23,31,44]. For HOXB9 studies by Zhan et al.[29] and Huang et al.[30] reported equivocal findings, (table 1). Most studies reported no significant association between tumour differentiation and HOX expression level, except for D9 where Liu et al. reported that high HOXD9 levels were significantly associated to poor differentiation[21]. Studies by Hoshino et al.[28] and Zhan et al.[29] have reported contradictory results regarding HOXB9 expression levels and its association with CRC differentiation, (table 1). Given the limited available data, it appears that there is no significant association between age, sex and CEA with HOX expression levels.

\section{HOX dysregulation and prognostic significance in CRC}

The HOX prognostic role (A3, B7, B8, C6, C11, D9, D10) was investigated by 14 studies[21-25,28-31,33,40,42-44]. Specifically, patients who were characterised by high HOX expression levels had significantly worse survival rates in comparison with the ones with low expression levels. Only two studies by $\mathrm{Ji}$ et al.[25] and Liao et al.[31] conducted multivariate analysis and reported that HOXC6 and HOXB7 are independent prognostic markers in patients with CRC, (table 1). HOXB9 was investigated by 4 studies which reported contradictory results with regards to its positive or negative impact on survival[28-30,42]. In terms of DFS, studies showed that high expression levels of HOXA3, A10, B8 and B9 were significantly associated with worse DFS rates in patients with $\mathrm{CRC}[23,24,33,40]$. HOXA10 and B9 were additionally reported to serve as independent risk factors for worse DFS by Yuan et al.[40] and Carbone et al.[24] respectively in a multivariate analysis model, (table 1 ).

\section{Functional role of HOX genes in CRC progression}

\section{Study characteristics}

Twenty-two studies investigated the functional role of HOX genes dysregulation in CRC progression[21-23,25,28-31,33,36,39,40,44-53]. All studies were preclinical with 11 having conducted in vivo experiments as well as in vitro. All in vitro experimental studies used various human colorectal cell lines to conduct gain and/or loss of function experiments by altering the gene expression level of the HOX gene of interest. In vivo studies used nude mice which were subjected to subcutaneous injection of human CRC cell lines with altered or not HOX expression level[21,23,25,28-31,33,40,52,53].

Twenty studies investigated the impact of HOX genes dysregulation on tumour growth, 8 of which performed additional in vivo experiments[21$23,25,28,29,31,33,36,39,40,44-51,53]$. The in vitro primary outcome as cell proliferation rate over time being measured by relevant assays, (table 2$)$. The in vivo primary outcome was tumour growth which was assessed differently in each study by reporting either tumour weight (gr), size (diameter in cm) or volume $\left(\mathrm{mm}^{3}\right)$, (table 2).

Ten studies investigated the effect of HOX genes differential expression in the metastatic potential in CRC[21,29,30,33,39,45-47,49,52]. Primary outcomes were the percentage of cells that showed invasion and/or migration in the relevant assays between the control versus the intervention group. Secondary outcomes were molecular markers involved in the Epithelial-Mesenchymal Transition (EMT) being reported by 6 studies[21,30,39,45,49,52]. Five studies provided additional results from in vivo experiments by assessing the number of lung/liver metastases as primary outcome[21,29,30,33,52], (table 2). One study reported markers involved in angiogenesis and vessel formation in vivo[28].

\section{Finding $\underline{s}$}

\section{HOX dysregulation and tumour growth in CRC}

Out of the $18 H O X$ genes and their protein products having been investigated to date, 15 were found to have oncogenic properties whereas only 3 were reported to exert tumour suppressive functions. Specifically, loss of function in vitro studies showed that knockdown of $H O X A 1, A 3, A 4, A 9, A 10, B 8, C 6, C 11$, $C 13$ and $D 3$ resulted in reduced proliferation rate of $C R C$ cells[22,23,25,33,40,44,47,48,50,51]. Additionally, overexpression in vitro experiments showed that increased levels of $H O X A 6, B 2, B 7$ and $D 9$ resulted in increased proliferation rates indicating the tumour promoting properties of the above gene products[21,31,39,46]. Findings from in vivo studies, which have been conducted for $H O X A 3, B 7, B 8, B 13, C 6$ and $D 9$, agreed with the functional role observed in vitro[21,23,25,31,33,53]. Findings for $H O X B 9$ by Hoshino et al.[28] and Zhan et al.[29] reported contradictory results with the former study reporting tumour promoting and the latter showing tumour suppressive properties in CRC. 
Nine HOX genes and their proteins have been reported to affect CRC disease progression in vitro[21,29,30,33,39,45-47,49,52]. Knockdown of HOXA1 and $H O X B 8$ resulted in a decreased number of invasive cells[33,47]. Similarly, overexpression of $H O X A 6, B 2$ and $D 9$ led to a significantly increased number of invasive and migratory cells in the intervention group $(21,39,46)$. On the contrary, overexpression of $H O X A 5, A 10$ and $D 8$ resulted in the decreased number of invasive and migratory cells in the intervention group[45,49,52], (table 2). In vivo findings agreed with the in vitro results regarding HOXA10 as mice who were injected with cells overexpressing A10 developed fewer metastases than the control group indicating a protective role of HOXA10 in CRC progression[52]. On the other hand, altered expression of HOXB8 and D9 showed the metastatic promoting effect of these genes in vivo[21,33]. (table 2). The expression of important EMT markers (E-cadherin and Vimentin) known to increase the invasive behaviour of cancer cells facilitating metastases, was altered between the intervention and control group. Specifically, downregulation of E-cadherin with subsequent upregulation of vimentin was observed in the studies investigating metastases-enhancer $H O X$ genes $(A 6, D 9, B 9)[21,30,39]$ whereas the opposite pattern was observed for the metastases-suppressors ones $(A 5, A 10, D 8)$ $[45,49,52]$, (table 2). Three studies reported findings regarding the role of HOXB9 in CRC progression; however the results are contradictory with Zhan et al. showing a metastatic promoting function whereas Huang et al. reported a tumour suppressive function[28-30].

\section{Discussion}

In recent years with the change in people's lifestyle and dietary factors, the incidence of CRC is increasing, especially in the younger population, making this disease a public health burden[54]. Since recurrence and development of distant metastases are the major causes of cancer-related mortality, it is crucial to investigate and discover new molecular markers that contribute to CRC aggressiveness and which may affect survival. We conducted this systematic review to investigate the clinicopathological and prognostic significance of HOX genes in CRC and determine the impact of their altered expression in CRC disease progression.

The present systematic review indicates that HOX genes become dysregulated in CRC in comparison with normal tissue and are a diverse group of genes as some may favour disease progression, whereas others act as tumour suppressors in CRC. The combination of clinical and preclinical findings of the studies included revealed that $H O X A 3, A 9, B 7, B 8, C 6, C 11$ and $D 9$ were found to be upregulated in CRC tissues[21-23,25,31,33,44]. Their high expression was correlated with adverse clinicopathological characteristics of $\mathrm{CRC}$ and worse survival outcomes suggesting an oncogenic role which was supported by the in vitro and in vivo experimental observations. On the other hand, HOXB13 and HOXD10 were found to be downregulated in CRC, and preclinical studies indicated a protective role towards disease progression[26,36]. Among the dysregulated HOX genes, most of them favour an oncogenic behaviour promoting disease progression rather than acting as tumour suppressors. Similar findings with our study were reported by a recent systematic review by Jin et al. on $H O X$ genes in gastric cancer (GC) which demonstrated diversity in the dysregulation profile of HOX genes with most of them acting as potential oncogenes and are associated with worse disease characteristics and worse 0S[55]. HOXB9 was the most frequently investigated gene; however, studies ( $n=5$ ) reported contradictory findings regarding its prognostic role in CRC with Carbone et al.[24], Hoshino et al.[28] and Huang et al.[30] showing a negative association with survival outcomes whereas Song et al.[42] and Zhan et al.[29] reported a positive one. Similarly, experimental findings were also opposing between studies regarding its tumour promoting or suppressive role, highlighting that HOX genes may also have a dual role in CRC progression depending on which mechanism is activated that regulates their function[56,57]. For instance, Wan et al. identified the acetylation of HOXB9 as an important post-translational modification which caused suppression of transcription of the HOXB9 target gene Jumonji domain-containing protein 6 (JMJD6) leading to inhibition of tumour growth and migration in lung adenocarcinoma, in vitro and in vivo[58]. HOXB9 acetylation was also shown by Song et al. to potentially be responsible for the HOXB9 potential protective role in CRC progression[42,58].

HOX genes contribute to a plethora of functionalities and can be regulated by transcriptional expression, regulating micro-RNAs and post-translational modifications that add complexity in understanding their role[59]. Therefore, the exact mechanism of how HOX genes promote CRC growth, invasion and metastasis has not yet been elucidated. HOX genes, as conserved developmental genes, have the ability to control various cellular functions responsible for cell survival and in many cancers seem to participate in cell proliferation(6). In CRC Liao et al., showed that HOXB7 could accelerate the transition from G1 to $S$ phase in cell cycle through the activation of PI3K/AKT and MAPK pathways resulting in upregulation of cyclin D1[31]. Additionally, Zhang et al. found that HOXA3 can serve as apoptosis-suppressor for cancer development through regulation of apoptosis-related factors (Bcl-2, caspase 3) and activation of EGFR/Ras/Raf/MEK/ERK pathway[23]. CRC progression to invasive and metastatic disease is characterised by the EMT process, which involves the transition of the stationary cancerous epithelial cells into motile mesenchymal ones enabling them to detach and metastasise[5]. HOX genes have been found to play an essential role in the EMT, promoting cell invasion and migration. In CRC, Liu et al. reported that HOXD9 promoted CRC cell invasion and migration through enhancing EMT by upregulating vimentin while downregulating E-cadherin[21]. This study also showed that HOXD9 might promote cell invasion and migration through the transforming growth factor-beta (TGF- $\beta$ ) pathway, which is an important pathway in the EMT process in CRC[5].

Angiogenesis plays a vital role in the progression of cancer, and various $H O X$ genes have been shown to function in promoting the formation of new vessels in solid tumours by upregulating angiogenic genes[6,60]. In CRC, Hoshino et al. showed that overexpression of $H O X B 9$ resulted in upregulation of angiogenic factors such as interleukin 8 (IL8) and vascular endothelial growth factor (VEGF) both in vitro and in vivo[28]. HOXB9 was also found to be of an important clinical significance as patients with high expression levels appeared to respond better to anti-angiogenic therapy with bevacizumab demonstrating longer OS and DFS in comparison with those who had low HOXB9 levels[28]. Interestingly, Carbone et al. reported the same effect of HOXB9 in the expression of angiogenic factors as Hoshino et al., however in vivo models showed that HOXB9 positive nude mice showed resistance to treatment with bevacizumab[24]. Either way, both studies demonstrate that $H O X B 9$ could serve as a potential marker for selecting treatment with anti-angiogenic chemotherapeutic drugs. The possible synergistic role of HOX genes modulation with chemotherapy treatment was shown by Yuan et al. for HOXA10, which was found to promote tumour progression in vitro and knockdown resulted in increased sensitivity to 5-Fluorouracil therapy in vitro and in vivo[40]. 
This systematic review is the first to provide cumulative current evidence regarding the role of $H O X$ genes in CRC progression, their clinicopathological and prognostic significance. This study outlines the heterogeneity among studies, as many have only investigated a specific HOX gene out of the 39 present in the human genome. Since the use of HOX genes as future biomarkers in CRC has recently started to attract research interest, further studies are warranted on the subject to fully explore the function of each HOX gene. This systematic review showed that few studies had been conducted to date which combine clinical and preclinical data (in vitro and in vivo) to thoroughly investigate the clinicopathological and functional role of a HOX gene in CRC progression. Moreover, studies demonstrated diversity in the study population characteristics included as well as variability in methodological approaches used. For instance, population characteristics varied between studies in terms of neoadjuvant chemotherapy administration. Furthermore, there was no established standardised cut-off point between high and low expression level and inconsistent criteria were used between studies to investigate the clinicopathological and prognostic role of the HOX gene of interest. It is worth highlighting the lack of power sample size reporting in both clinical and preclinical studies, as well as sample size information in some studies. For the reasons which include the diversity between studies, the lack of detailed and robust data a meta-analysis could not be conducted.

In conclusion, this systematic review provides the current cumulative evidence that HOX genes are dysregulated in patients with $\mathrm{CRC}$ and evaluates the association of their differential expression with the clinicopathological characteristics and prognosis. We have observed that altered expression of $H O X$ genes affects CRC progression in vitro and in vivo. Based on these findings, we propose HOX genes have potential as biomarkers or therapeutic targets in CRC[61]. Due to the complexity and heterogeneity of the HOX gene family, further well-conducted and even larger-scale or multicentre clinical and preclinical studies with robust methodology are needed to elucidate the role of each gene in CRC thus determining the validity of their role as potential biomarkers or therapeutic targets in CRC.

\section{Abbreviations}

AKT: protein kinase B

BRCA1: Breast Cancer gene 1

CEA: Carcinoembryonic antigen

CRC: Colorectal Cancer

DFS: Disease Free Survival

EGFR: Epidermal growth factor receptor

EMT: Epithelial Mesenchymal Transition

ERK: Extracellular signal-regulated kinases

HOX: Homeobox

IL8: Interleukin 8

JMJD6: Jumonji domain-containing protein 6

MAPK: mitogen-activated protein kinase

MEK: Mitogen-activated protein kinase

MeSH: Medical Subject Headings

NIH: National Heart, Lung and Blood Institute

OS: Overall Survival

PI3K: Phosphoinositide 3-kinase

PRISMA: Preferred Reported Items for Systematic Reviews and Meta-analyses

PROSPERO: Prospective Register of Systematic Reviews

RNA: Ribonucleic acid

SYRCLE'S: Systematic Review Centre for Laboratory animal experimentation

\section{Declarations}

Ethical Approval: Not applicable 
Consent for publications: All listed authors consented on the publication of this manuscript

Availability of data and material: All data and material are provided in the manuscript tables and figures as well as in the supplementary material.

Funding: No Funding has received for this study

Disclosure: The authors have declared no conflicts of interest.

Competing Interests: Not applicable

Authorship contribution statement: All authors contributed to this systematic review. Idea was perceived by [Eirini Martinou], systematic review design was conducted by [Eirini Martinou], [Angeliki Angelidi] and [Giulia Falgari]. Literature search, data extraction and data analysis was performed by [Eirini Martinou], [Giulia Falgari] and [Angeliki Angelidi]. Critical assessment of data analysis results was conducted for by [Izhar Bagwan] and [Angeliki Angelidi]. Manuscript draft was written by [Eirini Martinou], [Giulia Falgari] and was critically revised by [Angeliki Angelidi] and [Izhar Bagwan]. All authors have read and approved the manuscript.

Acknowledgements: Dr Guy Simpson, Dr Lisiane Meira and Professor Nariman Karanjia for proofreading the manuscript and providing comments on improving scientific language.

\section{References}

1. Siegel RL, Miller KD, Jemal A. Cancer statistics, 2020. CA Cancer J Clin. 2020;Mar 5:doi: 10.3322/caac.21601. [Epub ahead of print].

2. Bray F, Ferlay J, Soerjomataram I, Siegel RL, Torre LA, Jemal A. Global cancer statistics 2018: GLOBOCAN estimates of incidence and mortality worldwide for 36 cancers in 185 countries. CA Cancer J Clin. 2018;68(6):394-424.

3. Chow FCL, Chok KSH. Colorectal liver metastases: An update on multidisciplinary approach. World J Hepatol. 2019;11(2):150-72.

4. East JE, Atkin WS, Bateman AC, Clark SK, Dolwani S, Ket SN, et al. British Society of Gastroenterology position statement on serrated polyps in the colon and rectum. Gut. 2017;66(7):1181-96.

5. Paschos KA, Majeed AW, Bird NC. Natural history of hepatic metastases from colorectal cancer - Pathobiological pathways with clinical significance. World J Gastroenterol. 2014;20(14):3719-37.

6. Li B, Huang Q, Wei GH. The role of hox transcription factors in cancer predisposition and progression. Cancers (Basel). $2019 ; 11(4): 528$.

7. Castelli-Gair Hombría J, Lovegrove B. Beyond homeosis - HOX function in morphogenesis and organogenesis. Differentiation. 2003;71(8):461-76.

8. J. Durston A, Wacker S, Bardine N, J. Jansen H. Time Space Translation: A Hox Mechanism for Vertebrate A-P Patterning. Curr Genomics. 2012;13(4):300-7.

9. Quinonez SC, Innis JW. Human HOX gene disorders. Mol Genet Metab. 2014;111(1):4-15.

10. Bhatlekar S, Fields JZ, Boman BM. HOX genes and their role in the development of human cancers. J Mol Med. 2014 Aug;92(8):811-23.

11. Collins CT, Hess JL. Role of HOXA9 in leukemia: Dysregulation, cofactors and essential targets. Oncogene. 2016;35(9):1090-8.

12. Gilbert PM, Mouw JK, Unger MA, Lakins JN, Gbegnon MK, Clemmer VB, et al. HOXA9 regulates BRCA1 expression to modulate human breast tumor phenotype. J Clin Invest. 2010;120(5):1535-50.

13. Zhang L, Wu Q, He C, Liang D, Yi Q, Shi J, et al. HOXB9 inhibits proliferation in gastric carcinoma cells via suppression of phosphorylated-Akt and NF-KBdependent Snail expression. Dig Liver Dis. 2019;51(1):157-65.

14. Hayashida T, Takahashi F, Chiba N, Brachtel E, Takahashi M, Godin-Heymann N, et al. HOXB9, a gene overexpressed in breast cancer, promotes tumorigenicity and lung metastasis. Proc Natl Acad Sci U S A. 2010;107(3):1100-5.

15. Haria D, Naora H. Homeobox Gene Deregulation: Impact on the Hallmarks of Cancer. Cancer Hallm. 2014;1(2-3):67-76.

Page $7 / 16$ 
16. Bhatlekar S, Fields JZ, Boman BM. Role of HOX genes in stem cell differentiation and cancer. Stem Cells Int. 2018;22;2018:3569493. doi: $10.1155 / 2018 / 3569493$.

17. Javed S, Langley SEM. Importance of HOX genes in normal prostate gland formation, prostate cancer development and its early detection. BJU International. 2014. p. 113(4):535-40.

18. Liberati A, Altman DG, Tetzlaff J, Mulrow C, Gøtzsche PC, loannidis JPA, et al. The PRISMA statement for reporting systematic reviews and metaanalyses of studies that evaluate health care interventions: Explanation and elaboration. J Clin Epidemiol. 2009;62(10):e1-34.

19. Zeng X, Zhang Y, Kwong JSW, Zhang C, Li S, Sun F, et al. The methodological quality assessment tools for preclinical and clinical studies, systematic review and meta-analysis, and clinical practice guideline: A systematic review. J Evid Based Med. 2015;8(1):2-10.

20. Hooijmans CR, Rovers MM, De Vries RBM, Leenaars M, Ritskes-Hoitinga M, Langendam MW. SYRCLE's risk of bias tool for animal studies. BMC Med Res Methodol. 2014;14: 43:doi: 10.1186/1471-2288-14-43.

21. Liu M, Xiao Y, Tang W, Li J, Hong L, Dai W, et al. HOXD9 promote epithelial-mesenchymal transition and metastasis in colorectal carcinoma. Cancer Med. 2020;9(11):3932-43.

22. Cui Y, Zhang C, Wang Y, Ma S, Cao W, Guan F. HOXC11 functions as a novel oncogene in human colon adenocarcinoma and kidney renal clear cell carcinoma. Life Sci. 2020;243:117230.

23. Zhang X, Liu G, Ding L, Jiang T, Shao S, Gao Y, et al. HOXA3 promotes tumor growth of human colon cancer through activating EGFR/Ras/Raf/MEK/ERK signaling pathway. J Cell Biochem. 2018;119(3):2864-74.

24. Carbone C, Piro G, Simionato F, Ligorio F, Cremolini C, Loupakis F, et al. Homeobox B9 mediates resistance to anti-VEGF therapy in colorectal cancer patients. Clin Cancer Res. 2017;23(15):4312-22.

25. Ji M, Feng Q, He G, Yang L, Tang W, Lao X, et al. Silencing homeobox C6 inhibits colorectal cancer cell proliferation. Oncotarget. 2016;7(20):29216-27.

26. Wang Y, Li Z, Zhao X, Zuo X, Peng Z. MiR-10b promotes invasion by targeting HOXD10 in colorectal cancer. Oncol Lett. 2016;12(1):488-94.

27. Shen S, Pan J, Lu X, Chi P. Role of miR-196 and its target gene HoxB8 in the development and proliferation of human colorectal cancer and the impact of neoadjuvant chemotherapy with FOLFOX4 on their expression. Oncol Lett. 2016;12(5):4041-7.

28. Hoshino Y, Hayashida T, Hirata A, Takahashi H, Chiba N, Ohmura M, et al. Bevacizumab terminates homeobox B9-induced tumor proliferation by silencing microenvironmental communication. Mol Cancer. 2014;5;13:102.

29. Zhan J, Niu M, Wang P, Zhu X, Li S, Song J, et al. Elevated HOXB9 expression promotes differentiation and predicts a favourable outcome in colon adenocarcinoma patients. Br J Cancer. 2014;111(5):883-93.

30. Huang K, Yuan R, Wang K, Hu J, Huang Z, Yan C, et al. Overexpression of HOXB9 promotes metastasis and indicates poor prognosis in colon cancer. Chinese J Cancer Res. 2014;26(1):72-80.

31. Liao WT, Jiang D, Yuan J, Cui YM, Shi XW, Chen CM, et al. HOXB7 as a prognostic factor and mediator of colorectal cancer progression. Clin Cancer Res. 2011;17(11):3569-78.

32. Kanai M, Hamada JI, Takada M, Asano T, Murakawa K, Takahashi Y, et al. Aberrant expressions of HOX genes in colorectal and hepatocellular carcinomas. Oncol Rep. 2010;23(3):843-51.

33. Ying Y, Wang Y, Huang X, Sun Y, Zhang J, Li M, et al. Oncogenic HOXB8 is driven by MYC-regulated super-enhancer and potentiates colorectal cancer invasiveness via BACH1. Oncogene. 2020;39:1004-17.

34. Cantile M, Franco R, Tschan A, Baumhoer D, Zlobec I, Schiavo G, et al. HOX D13 expression across 79 tumor tissue types. Int J Cancer. 2009;125(7):1532-41.

35. Groene J, Mansmann U, Meister R, Staub E, Roepcke S, Heinze M, et al. Transcriptional census of 36 microdissected colorectal cancers yields a gene signature to distinguish UICC II and III. Int J Cancer. 2006;119(8):1829-36.

36. Jung C, Kim RS, Zhang H, Lee SJ, Sheng H, Loehrer PJ, et al. HOXB13 is downregulated in colorectal cancer to confer TCF4-mediated transactivation. Br J Cancer. 2005;92(12):2233-9.

37. Toiyama Y, Mizoguchi A, Kimura K, Araki T, Yoshiyama S, Sakaguchi K, et al. Persistence of gene expression changes in noninflamed and inflamed colonic mucosa in ulcerative colitis and their presence in colonic carcinoma. World J Gastroenterol. 2005;11(33):5151-5.

38. Vider BZ, Zimber A, Hirsch D, Estlein D, Chastre E, Prevot S, et al. Human colorectal carcinogenesis is associated with deregulation of homeobox gene expression. Biochem Biophys Res Commun. 1997;232(3):742-8. 
39. Wu S, Wu F, Jiang Z. Effect of HOXA6 on the proliferation, apoptosis, migration and invasion of colorectal cancer cells. Int J Oncol. 2018;52(6):2093100.

40. Yuan Y, Sun S, Jiao N, Shu Y, Zhang Y. Upregulation of HOXA10 Protein Expression Predicts Poor Prognosis for Colorectal Cancer. Genet Test Mol Biomarkers. 2018;22(6):1-8.

41. Tatangelo F, Di Mauro A, Scognamiglio G, Aquino G, Lettiero A, Delrio P, et al. Posterior HOX genes and HOTAIR expression in the proximal and distal colon cancer pathogenesis. J Trans/ Med. 2018;16(1):350.

42. Song J, Wang T, Xu W, Wang P, Wan J, Wang Y, et al. HOXB9 acetylation at K27 is responsible for its suppression of colon cancer progression. Cancer Lett. 2018;10;426:63-72.

43. Bhatlekar S, Fields JZ, Boman BM. Role of HOX genes in stem cell differentiation and cancer. Stem Cells Int. 2018;22;2018:35.

44. Watanabe $\mathrm{Y}$, Saito $\mathrm{M}$, Saito $\mathrm{K}$, Matsumoto $\mathrm{Y}$, Kanke $\mathrm{Y}$, Onozawa $\mathrm{H}$, et al. Upregulated HOXA9 expression is associated with lymph node metastasis in colorectal cancer. Oncol Lett. 2018;15(3):2756-62.

45. Mansour MA, Senga T. HOXD8 exerts a tumor-suppressing role in colorectal cancer as an apoptotic inducer. Int J Biochem Cell Biol. 2017;88:1-13.

46. Li H, Zhu G, Xing Y, Zhu Y, Piao D. miR-4324 functions as a tumor suppressor in colorectal cancer by targeting HOXB2. J Int Med Res. 2020;48(3):300060519883731.

47. Li H, Li J, Yang T, Lin S, Li H. MicroRNA-433 represses proliferation and invasion of colon cancer cells by targeting homeobox A1. Oncol Res. 2018;26(2):315-22.

48. Bhatlekar S, Viswanathan V, Fields JZ, Boman BM. Overexpression of HOXA4 and HOXA9 genes promotes self-renewal and contributes to colon cancer stem cell overpopulation. J Cell Physiol. 2018;233(2):727-35.

49. Han Y, Zhao Q, Zhou J, Shi R. miR-429 mediates tumor growth and metastasis in colorectal cancer. Am J Cancer Res. 2017;7(2):218-33.

50. Chen F, Sun G, Peng J. RNAi-mediated HOXD3 knockdown inhibits growth in human RKO cells. Oncol Rep. 2016;36(4):1793-8.

51. Kasiri S, Ansari KI, Hussain I, Bhan A, Mandal SS. Antisense oligonucleotide mediated knockdown of HOXC13 affects cell growth and induces apoptosis in tumor cells and over expression of HOXC13 induces 3D-colony formation. RSC Adv. 2013;3(10):3260-9.

52. Sun S, Su C, Zhu Y, Li H, Liu N, Xu T, et al. MicroRNA-544a Regulates Migration and Invasion in Colorectal Cancer Cells via Regulation of Homeobox A10. Dig Dis Sci. 2016;61(9):2535-44.

53. Ghoshal K, Motiwala T, Claus R, Yan P, Kutay H, Datta J, et al. HOXB13, a target of DNMT3B, is methylated at an upstream CpG island, and functions as a tumor suppressor in primary colorectal tumors. PLoS One. 2010;5(4):e10338.

54. Saad El Din K, Loree JM, Sayre EC, Gill S, Brown CJ, Dau H, et al. Trends in the epidemiology of young-onset colorectal cancer: A worldwide systematic review. BMC Cancer. 2020;20(1:288):doi: 10.1186/s12885-020-06766-9.

55. Jin X, Dai L, Ma Y, Wang J, Yan H, Jin Y, et al. Homeobox proteins are potential biomarkers and therapeutic targets in gastric cancer: A systematic review and meta-analysis. BMC Cancer. 2020;20(1):866. doi: 10.1186/s12885-020-07346-7.

56. Yu M, Zhan J, Zhang H. HOX family transcription factors: Related signaling pathways and post-translational modifications in cancer. Cell Signal. 2020;66:doi: 10.1016/j.cellsig.2019.109469.

57. Kachgal S, Mace KA, Boudreau NJ. The dual roles of homeobox genes in vascularisation and wound healing. Cell Adhes Migr. 2012;6(6):457-70.

58. Wan J, Xu W, Zhan J, Ma J, Li X, Xie Y, et al. PCAF-mediated acetylation of transcriptional factor HOXB9 suppresses lung adenocarcinoma progression by targeting oncogenic protein JMJD6. Nucleic Acids Res. 2016;44(22):10662-75.

59. Ladam F, Sagerström CG. Hox regulation of transcription: More complex(es). Dev Dyn. 2014;243(1):4-15.

60. Contarelli S, Fedele V, Melisi D. HOX genes family and cancer: A novel role for homeobox B9 in the resistance to anti-angiogenic therapies. Cancers (Basel). 2020;21(11):3299, doi: 10.3390/cancers12113299.

61. Morgan R, El-Tanani M, Hunter KD, Harrington KJ, Pandha HS. Targeting HOX/PBX dimers in cancer. Oncotarget. 2017;8(19):32322-31.

\section{Tables}

Table 1. Included studies reporting on clinicopathological and prognostic significance of HOX genes in CRC. $*: p<0.05, * *: p<0.01, * \star *: p<0.001$ 


\begin{tabular}{|c|c|c|c|c|c|c|c|c|c|c|c|c|c|c|c|}
\hline \multirow[t]{2}{*}{$\begin{array}{l}\text { Author } \\
\text { (year) }\end{array}$} & \multirow[t]{2}{*}{ Gene } & \multirow[t]{2}{*}{$\begin{array}{l}\text { Patients } \\
(\% \mathrm{M})\end{array}$} & \multirow[t]{2}{*}{$\begin{array}{l}\text { Age } \\
\text { (ys) }\end{array}$} & \multirow[t]{2}{*}{ Stage } & \multirow[t]{2}{*}{$\begin{array}{l}\text { FUP(m) } \\
(\max )\end{array}$} & \multirow[t]{2}{*}{ Sample } & \multirow[t]{2}{*}{ Methods } & \multirow[t]{2}{*}{$\begin{array}{l}\text { DE } \\
\text { (C vs } \\
\text { N) }\end{array}$} & \multicolumn{7}{|c|}{$\begin{array}{l}\text { HOX overexpression association with } \\
\text { clinicopathological characteristics } \\
\text { (positive or negative) }\end{array}$} \\
\hline & & & & & & & & & Age & Sex & $T$ & $\mathbf{N}$ & $M$ & $s$ & G \\
\hline & HOXD9 & 100 & NR & $\mathrm{I}-\mathrm{IV}$ & NR & FFPE & $\mathrm{IHC}$ & $\uparrow$ & NS & NS & NS & $\uparrow$ & NR & $\uparrow$ & $\uparrow$ \\
\hline $\begin{array}{l}\text { Liu et } \\
a^{(21)} \\
(2020)\end{array}$ & & $(59 \%)$ & & & & & & $\star * *$ & & & & * & & * &  \\
\hline $\begin{array}{l}\text { Cui et al } \\
(22) \\
(2019)\end{array}$ & HOXC11 & $\begin{array}{l}265 \\
(\mathrm{NR})\end{array}$ & NR & NR & $\mathrm{NR}$ & NR & $\begin{array}{l}\text { Data } \\
\text { mining }\end{array}$ & $\begin{array}{l}\uparrow \\
*\end{array}$ & $\mathrm{NR}$ & $N R$ & NR & NR & $N R$ & $N R$ & NR \\
\hline \multirow{3}{*}{$\begin{array}{l}\text { Ying et al } \\
(22)\end{array}$} & HOXB8 & 80 & NR & $\mathrm{H}-\mathrm{IV}$ & 120 & NR & qRT-PCR & $\uparrow$ & NS & NS & NR & $\uparrow$ & $N R$ & $\uparrow$ & NS \\
\hline & & $(59 \%)$ & & & & & & * & & & & & & & \\
\hline & & $\begin{array}{l}510 \\
(\mathrm{NR})\end{array}$ & NR & NR & 120 & NR & $\begin{array}{l}\text { Data } \\
\text { mining }\end{array}$ & $\begin{array}{l}\uparrow \\
* *\end{array}$ & NS & NS & $\uparrow$ & NS & $\uparrow$ & NS & NS \\
\hline $\begin{array}{l}\text { Wu et al } \\
(22) \\
(2018)\end{array}$ & HOXA6 & $\begin{array}{l}16 \\
(63 \%)\end{array}$ & $\begin{array}{l}49- \\
80\end{array}$ & NR & $\mathrm{NR}$ & NR & qRT-PCR & $\begin{array}{l}\uparrow \\
\text { * }\end{array}$ & $\mathrm{NR}$ & NR & $\mathrm{NR}$ & $\mathrm{NR}$ & NR & NR & NR \\
\hline $\begin{array}{l}\text { Yuan et al } \\
(40) \\
(2018)\end{array}$ & HOXA10 & $\begin{array}{l}85 \\
(58 \%)\end{array}$ & $\begin{array}{l}26- \\
80\end{array}$ & II-IV & 60 & FFPE & $\mathrm{IHC}$ & $\begin{array}{l}\uparrow \\
\star \star *\end{array}$ & NS & NS & NS & NS & $N R$ & NS & NS \\
\hline \multirow{4}{*}{$\begin{array}{l}\text { Tatangelo } \\
\text { et } a^{(41)} \\
(2018)\end{array}$} & HOXA13 & 82 & $50-$ & I-IV & $\mathrm{NR}$ & FFPE & $\mathrm{IHC}$ & $\uparrow$ & NS & NS & NS & NS & $\mathrm{NR}$ & $N R$ & NS \\
\hline & HOXB13 & $(54 \%)$ & & & & & & $\uparrow$ & $\uparrow$ & $\uparrow$ & NS & $\begin{array}{l}\uparrow \\
\text { ** }\end{array}$ & $N R$ & & \\
\hline & HOXC13 & & & & & & & $\uparrow$ & NS & NS & NS & $\uparrow$ & NR & & \\
\hline & HOXD13 & & & & & & & $\uparrow$ & NS & NS & NS & NS & $N R$ & & \\
\hline $\begin{array}{l}\text { Song et al } \\
(42) \\
(2018)\end{array}$ & АсК27-HOХB9 & $\begin{array}{l}90 \\
(51 \%)\end{array}$ & $\begin{array}{l}24- \\
90\end{array}$ & $\mathrm{H}-\mathrm{IV}$ & 73 & FFPE & $\mathrm{IHC}$ & $\begin{array}{l}\downarrow \\
\star \star \star\end{array}$ & $\begin{array}{l}\uparrow \\
\text { * }\end{array}$ & NS & NS & NS & NR & $\downarrow$ & NR \\
\hline $\begin{array}{l}\text { Bhatlekar } \\
\text { et al (43) } \\
(2018)\end{array}$ & $\begin{array}{l}\text { HOXA4, } \\
\text { HOXD1O }\end{array}$ & $\begin{array}{l}3 \\
\text { (NR) }\end{array}$ & NR & NR & $\mathrm{NR}$ & FT & $\begin{array}{l}\text { qRT- } \\
\text { PCR/IHC }\end{array}$ & $\begin{array}{l}\uparrow \\
(\mathrm{NR})\end{array}$ & $N R$ & NR & NR & NR & NR & $N R$ & NR \\
\hline $\begin{array}{l}\text { Watanabe } \\
\text { et al (44) } \\
(2017)\end{array}$ & HOXA9 & $\begin{array}{l}231 \\
(58.9 \%)\end{array}$ & NR & $\mathrm{H}-\mathrm{IV}$ & 100 & $\begin{array}{l}\text { FT } \\
\text { FFPE }\end{array}$ & $\begin{array}{l}\text { qRT- } \\
\text { PCR/IHC }\end{array}$ & $\begin{array}{l}\uparrow \\
\star \star \star\end{array}$ & NS & NS & NS & $\begin{array}{l}\uparrow \\
*\end{array}$ & NS & $\begin{array}{l}\uparrow \\
*\end{array}$ & NR \\
\hline
\end{tabular}




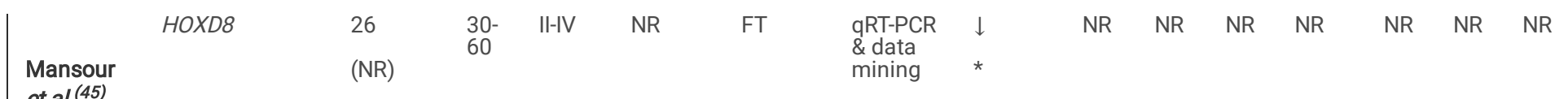

(2017)

\begin{tabular}{|c|c|c|c|c|c|c|c|c|c|c|c|c|c|c|c|}
\hline & HOXАЗ & 232 & NR & I-IV & 140 & FFT & qRT-PCR & $\uparrow$ & NR & NR & NR & NR & NR & $\uparrow$ & NR \\
\hline $\begin{array}{l}\text { Zhang et } \\
\text { al (23) }\end{array}$ & & $(61 \%)$ & & & & & & $\star *$ & & & & & & $\star \star$ & \\
\hline
\end{tabular}

\begin{tabular}{|c|c|c|c|c|c|c|c|c|c|c|c|c|c|c|c|}
\hline $\begin{array}{l}\text { Carbone } \\
\text { et al (24) }\end{array}$ & НОХВ9 & $\begin{array}{l}58 \\
(53 \%)\end{array}$ & $\begin{array}{l}25- \\
84\end{array}$ & I-IV & NR & FFPE & $\mathrm{IHC}$ & NR & NS & NR & $\begin{array}{l}\uparrow \\
*\end{array}$ & NR & $\uparrow$ & NR & NR \\
\hline (2017) & & & & & & & & & & & & & & & \\
\hline
\end{tabular}

\begin{tabular}{|c|c|c|c|c|c|c|c|c|c|c|c|c|c|c|c|}
\hline Ji et al & HOXC6 & 462 & NR & HIV & 84 & FFPE & $\mathrm{IHC}$ & $\uparrow$ & NS & NS & $\uparrow$ & $\uparrow$ & NS & NR & NS \\
\hline (2016) & & $(61 \%)$ & & & & & & $\star \star * *$ & & & $\star \star \star$ & $\star * *$ & & & \\
\hline
\end{tabular}

\begin{tabular}{|c|c|c|c|c|c|c|c|c|c|c|c|c|c|c|c|}
\hline & HOXD10 & & NR & $I-I I I$ & NR & FFT & $\begin{array}{l}\text { qRT- } \\
\text { PCR/IHC }\end{array}$ & & NR & NR & NR & & NR & NR & NR \\
\hline $\begin{array}{l}\text { Wang et } \\
\text { al(26) }\end{array}$ & & (59\%) & & & & & & $\star \star$ & & & & ** & & & \\
\hline
\end{tabular}

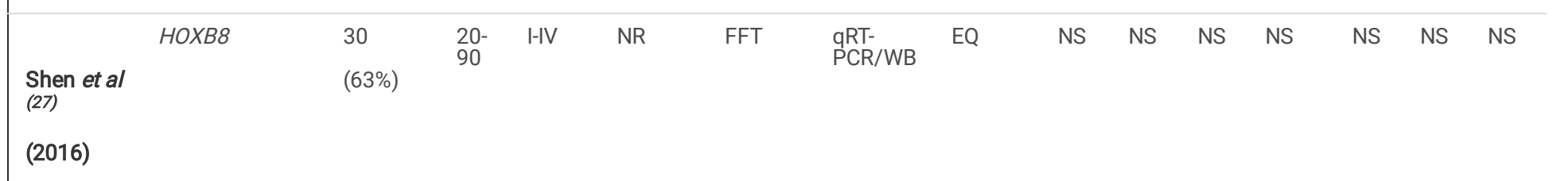

\begin{tabular}{|c|c|c|c|c|c|c|c|c|c|c|c|c|c|c|c|}
\hline $\begin{array}{l}\text { Hoshino } \\
\text { et al (28) }\end{array}$ & HOXB9 & $\begin{array}{l}93 \\
(\mathrm{NR})\end{array}$ & NR & $\| I I I$ & NR & $\begin{array}{l}\text { FFT } \\
\text { FFPE }\end{array}$ & $\begin{array}{l}\text { qRT- } \\
\text { PCR/IHC }\end{array}$ & $\begin{array}{l}\uparrow \\
(\mathrm{NR})\end{array}$ & NR & NR & NR & NR & NR & NR & $\begin{array}{l}\uparrow \\
\star \star \star\end{array}$ \\
\hline (2014) & & & & & & & & & & & & & & & \\
\hline
\end{tabular}

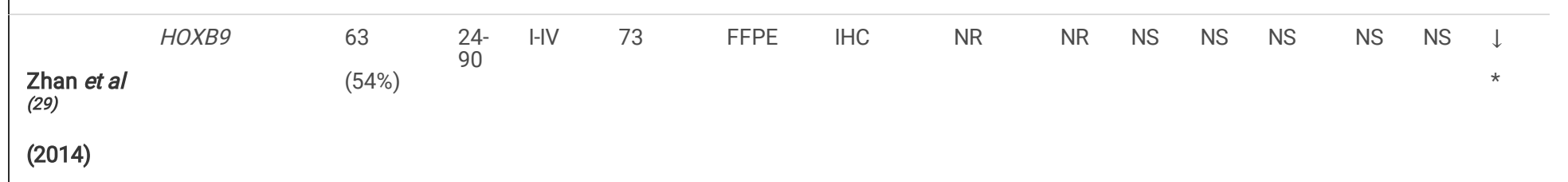

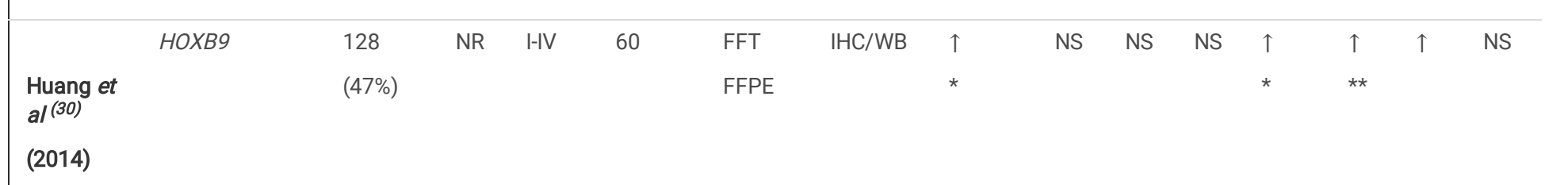

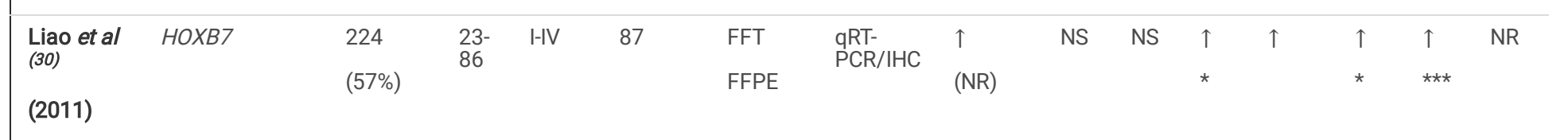

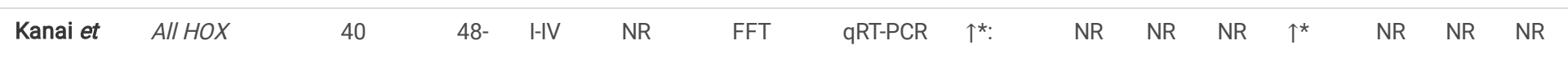




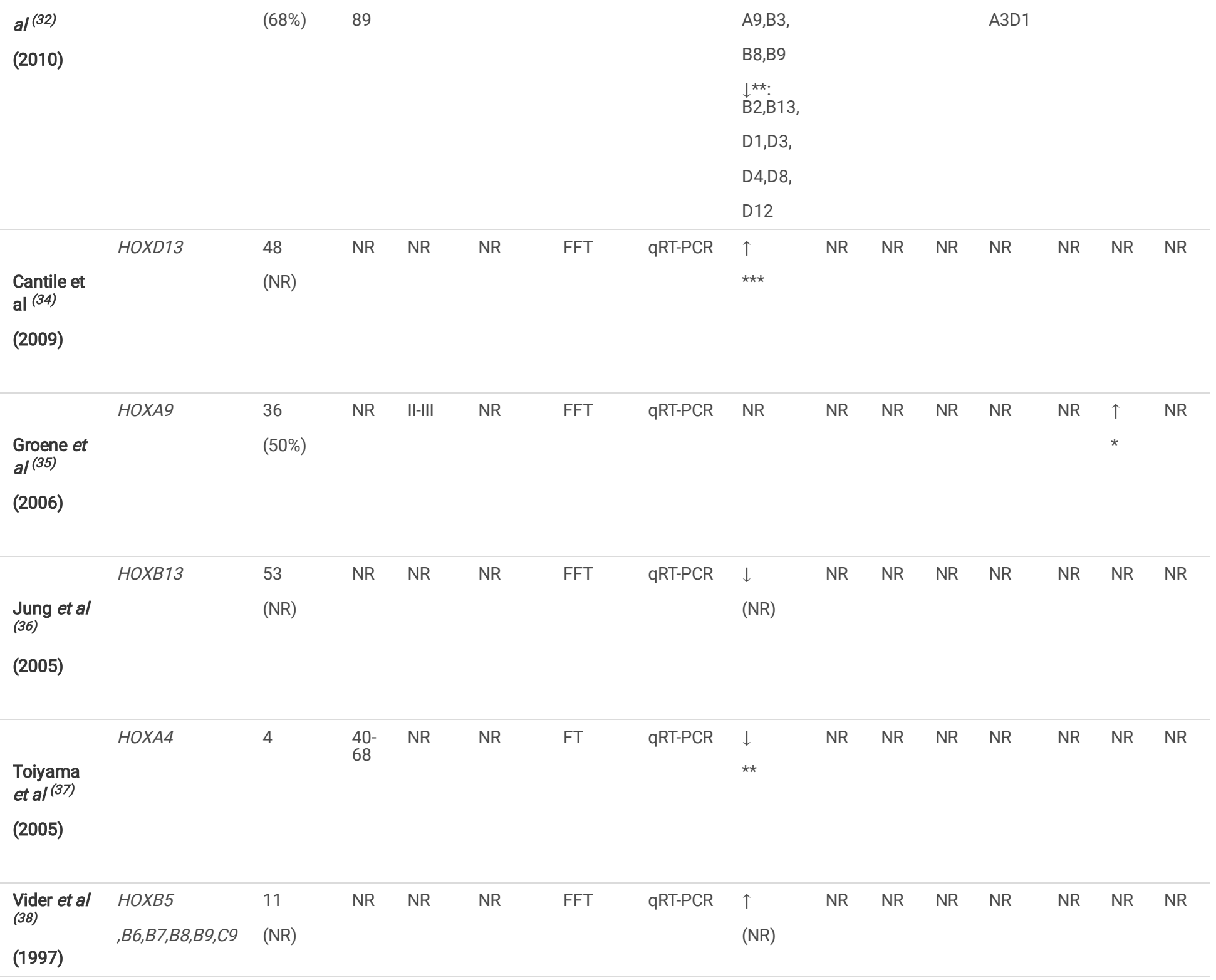

\%M: percentage of male patients, FUP: Follow up, DE: Differential Expression, C: Cancerous tissue, N: Normal colon tissue, T: Tumour depth, N: Lymph node s disease, S: Stage, G: Grade, CEA: Carcinoembryonic antigen, DFS: Disease Free Survival, OS: Overall Survival, NR: Not Reported, EQ: Equivocal findings, FFPE: FT: Fresh Tissue, FFT: Fresh Frozen Tissue, IHC: Immunohistochemistry, WB: Western Blot, NS: Not Significant, RT-qPCR: Real Time Quantitative Polymerase Cl: Confidence Intervals

Table 2. Included studies reporting on the functional role of HOX genes dysregulation in CRC progression. $*: p<0.05, * *: p<0.01, * \star *: p<0.001$

\section{Figures}




\begin{tabular}{|c|c|c|c|c|c|c|c|c|c|c|c|c|}
\hline \multirow[t]{2}{*}{$\begin{array}{l}\text { Author } \\
\text { (year) }\end{array}$} & \multirow[t]{2}{*}{ Gene } & \multirow[t]{2}{*}{$\begin{array}{l}\text { Cell } \\
\text { lines }\end{array}$} & \multirow[t]{2}{*}{ Intervention } & \multirow[t]{2}{*}{ Endpoint assays } & \multicolumn{6}{|c|}{$\begin{array}{l}\text { Outcomes } \\
\text { (intervention vs control cell line group) }\end{array}$} & \multirow{2}{*}{$\begin{array}{l}\text { Nude } \\
\text { mice } \\
\text { (type, } \\
\text { n) }\end{array}$} & \multirow[t]{2}{*}{ Intervention } \\
\hline & & & & & PR & CLF & AP & INV & MIGR & $\begin{array}{l}\text { Molecular } \\
\text { markers }\end{array}$ & & \\
\hline \multicolumn{13}{|c|}{ In Vitro studies } \\
\hline $\begin{array}{l}\text { Cui et } \\
a l(22) \\
(2019)\end{array}$ & HOXC11 & SW480 & $\begin{array}{l}\text { siRNA } \\
(K D)\end{array}$ & $\begin{array}{l}\text { Proliferation (CCK- } \\
8) \\
\text { Flow cytometry }\end{array}$ & $\begin{array}{l}\downarrow \\
\star\end{array}$ & NR & $\begin{array}{l}\uparrow \\
*\end{array}$ & NR & NR & NR & - & - \\
\hline $\begin{array}{l}\mathrm{Li} e t \\
\mathrm{al}^{(46)} \\
(2019)\end{array}$ & HOXB2 & $\begin{array}{l}\text { SW620 } \\
\text { SW480 }\end{array}$ & $\begin{array}{l}\text { Plasmid } \\
(\mathrm{OE})\end{array}$ & $\begin{array}{l}\text { Proliferation } \\
\text { (MTT) } \\
\text { Wound healing } \\
\text { Transwell invasion }\end{array}$ & $\begin{array}{l}\uparrow \\
\star * *\end{array}$ & NR & $N R$ & $\begin{array}{l}\uparrow \\
\star *\end{array}$ & $\begin{array}{l}\uparrow \\
\star *\end{array}$ & NR & - & - \\
\hline $\begin{array}{l}\text { Wu et } \\
a l^{(39)} \\
(2018)\end{array}$ & HOXA6 & $\begin{array}{l}\text { HT29 } \\
\text { Caco-2 }\end{array}$ & $\begin{array}{l}\text { Plasmid } \\
\text { (OE) } \\
\text { ShRNA } \\
\text { (KD) }\end{array}$ & $\begin{array}{l}\text { Proliferation (CCK- } \\
\text { 8) } \\
\text { Colony formation } \\
\text { Transwell } \\
\text { invasion/migration } \\
\text { Flow cytometry }\end{array}$ & $\begin{array}{l}\uparrow \\
\star * *\end{array}$ & $\begin{array}{l}\uparrow \\
\star *\end{array}$ & $\begin{array}{l}\downarrow \\
\star *\end{array}$ & $\begin{array}{l}\uparrow \\
\star * *\end{array}$ & $\begin{array}{l}\uparrow \\
\star \star \star\end{array}$ & 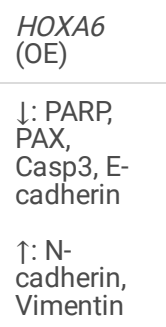 & - & - \\
\hline $\begin{array}{l}\mathrm{Li} e t \\
a^{(47)} \\
(2018)\end{array}$ & HOXA1 & SW620 & $\begin{array}{l}\text { siRNA } \\
(K D)\end{array}$ & $\begin{array}{l}\text { Proliferation (CCK- } \\
8) \\
\text { Transwell invasion }\end{array}$ & $\begin{array}{l}\downarrow \\
\star *\end{array}$ & NR & $N R$ & $\begin{array}{l}\downarrow \\
\star *\end{array}$ & NR & NR & - & - \\
\hline $\begin{array}{l}\text { Watanabe } \\
\text { et al }{ }^{(44)} \\
(2018)\end{array}$ & HOXA9 & $\begin{array}{l}\text { HCT116, } \\
\text { LoVo } \\
\text { RKO, } \\
\text { LS174T } \\
\text { Colo205 } \\
\text { Colo201 } \\
\text { SW620, } \\
\text { LS180 } \\
\text { SW83, } \\
\text { SW480 } \\
\text { HCT15, } \\
\text { SW480 }\end{array}$ & $\begin{array}{l}\text { SiRNA } \\
(K D)\end{array}$ & $\begin{array}{l}\text { Proliferation } \\
\text { (trypan blue) }\end{array}$ & NS & NR & NR & NR & NR & NR & - & - \\
\hline $\begin{array}{l}\text { Bhatlekar } \\
\text { et al } \\
(28) \\
(2018)\end{array}$ & $\begin{array}{l}\text { HOXA4 } \\
\text { HOXA9 }\end{array}$ & $\begin{array}{l}\text { SW480 } \\
\text { HT29 }\end{array}$ & $\begin{array}{l}\text { siRNA } \\
(\mathrm{KD})\end{array}$ & $\begin{array}{l}\text { Proliferation (WST- } \\
\text { 1) } \\
\text { Colony formation }\end{array}$ & $\begin{array}{l}\downarrow \\
\star *\end{array}$ & $\begin{array}{l}\downarrow \\
\star *\end{array}$ & NR & NR & NR & NR & - & - \\
\hline $\begin{array}{l}\text { Mansour } \\
\text { et al } \\
(25) \\
(2017)\end{array}$ & HOXD8 & $\begin{array}{l}\text { HCT116, } \\
\text { DLD-1 } \\
\text { HT29, } \\
\text { SW620 } \\
\text { SW1080 }\end{array}$ & $\begin{array}{l}\text { Retrovirus } \\
(\mathrm{OE})\end{array}$ & $\begin{array}{l}\text { Proliferation } \\
\text { (MTT) } \\
\text { Colony formation } \\
\text { Apoptosis } \\
\text { Transwell invasion }\end{array}$ & $\begin{array}{l}\downarrow \\
*\end{array}$ & $\begin{array}{l}\downarrow \\
*\end{array}$ & $\begin{array}{l}\uparrow \\
*\end{array}$ & $\begin{array}{l}\downarrow \\
\star\end{array}$ & NR & $\begin{array}{l}\uparrow: \text { Caspase } \\
6,7, \text { PARP } \\
\text { E-cadherin }\end{array}$ & - & - \\
\hline $\begin{array}{l}\text { Han et } \\
a^{(}(49) \\
(2017)\end{array}$ & HOXA5 & $\begin{array}{l}\text { НСТ116 } \\
\text { НT29 }\end{array}$ & $\begin{array}{l}\text { Plasmid } \\
(\mathrm{OE})\end{array}$ & $\begin{array}{l}\text { Proliferation (CCK- } \\
\text { 8) } \\
\text { Colony formation } \\
\text { Transwell } \\
\text { invasion/migration }\end{array}$ & $\begin{array}{l}\downarrow \\
\star *\end{array}$ & $\begin{array}{l}\downarrow \\
\star *\end{array}$ & NR & $\begin{array}{l}\downarrow \\
\star \star\end{array}$ & $\begin{array}{l}\downarrow \\
\star *\end{array}$ & $\begin{array}{l}\downarrow^{\star *}: \\
\text { Vimentin, } \\
\text { Fibronectin } \\
\uparrow * * \text { E- } \\
\text { cadherin, } \\
\text { a-catenin }\end{array}$ & - & - \\
\hline $\begin{array}{l}\text { Chen et } \\
a^{(50)} \\
(2016)\end{array}$ & HOXD3 & RKO & $\begin{array}{l}\text { Lentivirus } \\
\text { (KD) }\end{array}$ & $\begin{array}{l}\text { Proliferation } \\
\text { (MTT) } \\
\text { Colony formation } \\
\text { Flow cytometry }\end{array}$ & $\begin{array}{l}\downarrow \\
\star \star\end{array}$ & $\begin{array}{l}\downarrow \\
\star *\end{array}$ & $\begin{array}{l}\uparrow \\
\star *\end{array}$ & NR & NR & NR & - & - \\
\hline $\begin{array}{l}\text { Kasiri et } \\
a^{(51)} \\
(2013)\end{array}$ & HOXC13 & SW480 & $\begin{array}{l}\text { Antisense } \\
\text { nucleotide } \\
\text { (KD) }\end{array}$ & $\begin{array}{l}\text { Proliferation } \\
\text { (MTT) } \\
\text { Flow cytometry }\end{array}$ & $\begin{array}{l}\downarrow \\
*\end{array}$ & NR & $\begin{array}{l}\uparrow \\
(\mathrm{NR})\end{array}$ & NR & NR & $\begin{array}{l}\text { l: Cyclin B, } \\
\text { D, E }\end{array}$ & - & - \\
\hline
\end{tabular}




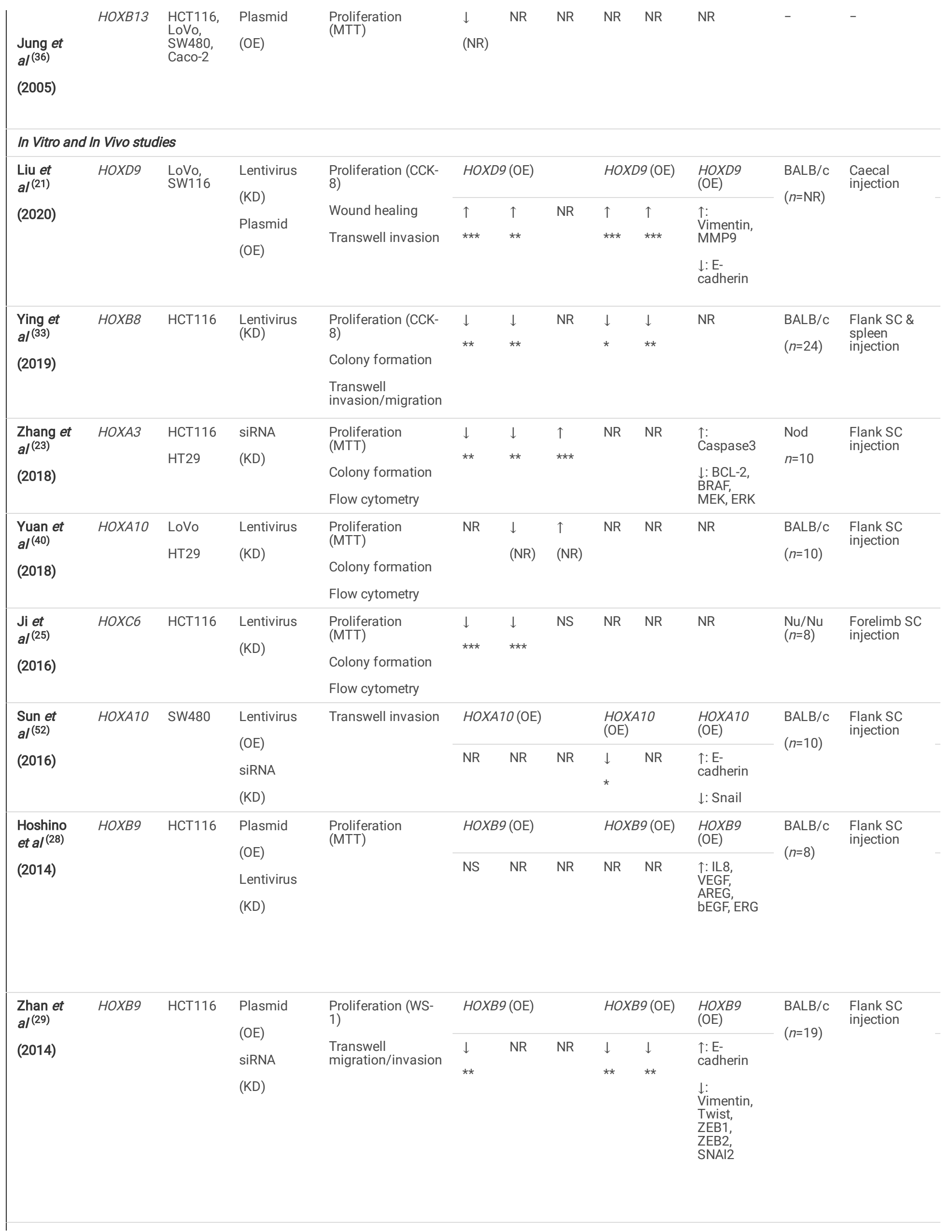




\begin{tabular}{|c|c|c|c|c|c|c|c|c|c|c|c|c|}
\hline \multirow{4}{*}{$\begin{array}{l}\text { Huang et } \\
a^{(30)} \\
(2013)\end{array}$} & \multirow[t]{4}{*}{ HOXB9 } & \multirow{4}{*}{$\begin{array}{l}\text { LoVo } \\
\text { SW620 }\end{array}$} & \multirow{4}{*}{$\begin{array}{l}\text { Retrovirus } \\
\text { (KD) } \\
\text { Plasmid } \\
(\mathrm{OE})\end{array}$} & \multirow{4}{*}{$\begin{array}{l}\text { Wound healing } \\
\text { Transwell } \\
\text { invasion/migration }\end{array}$} & \multicolumn{3}{|c|}{ HOXB9 (KD) } & \multicolumn{2}{|c|}{ HOXB9 (KD) } & \multirow[t]{4}{*}{ NR } & \multirow{4}{*}{$\begin{array}{l}\text { BALB/c } \\
(n=24)\end{array}$} & \multirow{4}{*}{$\begin{array}{l}\text { Orthotopic } \\
\text { implantation }\end{array}$} \\
\hline & & & & & \multirow[t]{3}{*}{ NR } & \multirow[t]{3}{*}{ NR } & \multirow[t]{3}{*}{ NR } & $\downarrow$ & $\downarrow$ & & & \\
\hline & & & & & & & & * & * & & & \\
\hline & & & & & & & & & & & & \\
\hline \multirow{4}{*}{$\begin{array}{l}\text { Liao et } \\
\text { al } \\
(31) \\
(2011)\end{array}$} & \multirow[t]{4}{*}{ HOXB7 } & \multirow{4}{*}{$\begin{array}{l}\text { HCT116, } \\
\text { Ls174t, } \\
\text { SW480, } \\
\text { SW620, } \\
\text { DLD-1 }\end{array}$} & \multirow{4}{*}{$\begin{array}{l}\text { Plasmid } \\
(\mathrm{OE}) \\
\text { Retrovirus } \\
(\mathrm{KD})\end{array}$} & Proliferation & \multicolumn{3}{|c|}{ HOXB7 (OE) } & \multicolumn{2}{|c|}{ HOXB7 (OE) } & HOXB7 & \multirow{4}{*}{$\begin{array}{l}\text { BALB/c } \\
(n=10)\end{array}$} & \multirow{4}{*}{$\begin{array}{l}\text { Flank SC } \\
\text { injection }\end{array}$} \\
\hline & & & & \multirow{3}{*}{ Colony formation } & $\uparrow$ & $\uparrow$ & NR & $N R$ & $N R$ & $\uparrow \cdot$ Cvclin & & \\
\hline & & & & & & & & & & D1, GSK3 $\beta$, & & \\
\hline & & & & & * & $\star \star \star$ & & & & ERK & & \\
\hline \multirow{3}{*}{$\begin{array}{l}\text { Ghoshal } \\
\text { et al } \\
(23) \\
(2010)\end{array}$} & \multirow[t]{3}{*}{ HOXB13 } & HCT116 & Plasmid & \multirow{2}{*}{$\begin{array}{l}\text { Proliferation } \\
\text { (MTT) }\end{array}$} & $\downarrow$ & $\downarrow$ & \multirow[t]{3}{*}{ NR } & \multirow[t]{3}{*}{ NR } & \multirow[t]{3}{*}{ NR } & \multirow[t]{3}{*}{ NR } & \multirow[t]{3}{*}{ NR } & \multirow{3}{*}{$\begin{array}{l}\text { Flank SC } \\
\text { injection }\end{array}$} \\
\hline & & \multirow[t]{2}{*}{ RKO } & \multirow[t]{2}{*}{$(\mathrm{OE})$} & & $\star \star$ & ** & & & & & & \\
\hline & & & & ony for & & & & & & & & \\
\hline
\end{tabular}

PR: Proliferation, CLF: Colony Formation, AP: Apoptosis, INV: Invasion, MIGR: Migration, KD: Knockdown, OE: Overexpression, ASO: Antisense Oligonucleotide Reported, CCK-8: Cell Counting Kit 8, MTT: 3-(4,5-dimethylthiazol-2-yl)-2,5-diphenyltetrazolium bromide, TV: Tumour Volume, TW: Tumour Weight, SC: Subcuti PARP: Poly [ADP-ribose] polymerase, PAX: Paired Box, MMP9: Matrix Metallopeptidase 9, BCL-2: BCL2 Apoptosis Regulator, BRAF: v-Raf murine sarcoma vira homolog B, MEK: Mitogen-Activated Protein Kinase Kinase, ERK: Rxtracellular-signal-Regulated Kinase, IL8: Interleukin 8, VEGF: Vascular endothelial growth Amphiregulin , bEGF: Endothelial growth factor beta, ERG: ETS transcription factor, ZEB1: Zinc Finger E-Box Binding Homeobox 1 , ZEB2: Zinc Finger E-Box Bi Homeobox 2 , GSK3 $\beta$ : Glycogen Synthase Kinase 3 Beta , Akt: AKT Serine/Threonine Kinase 1

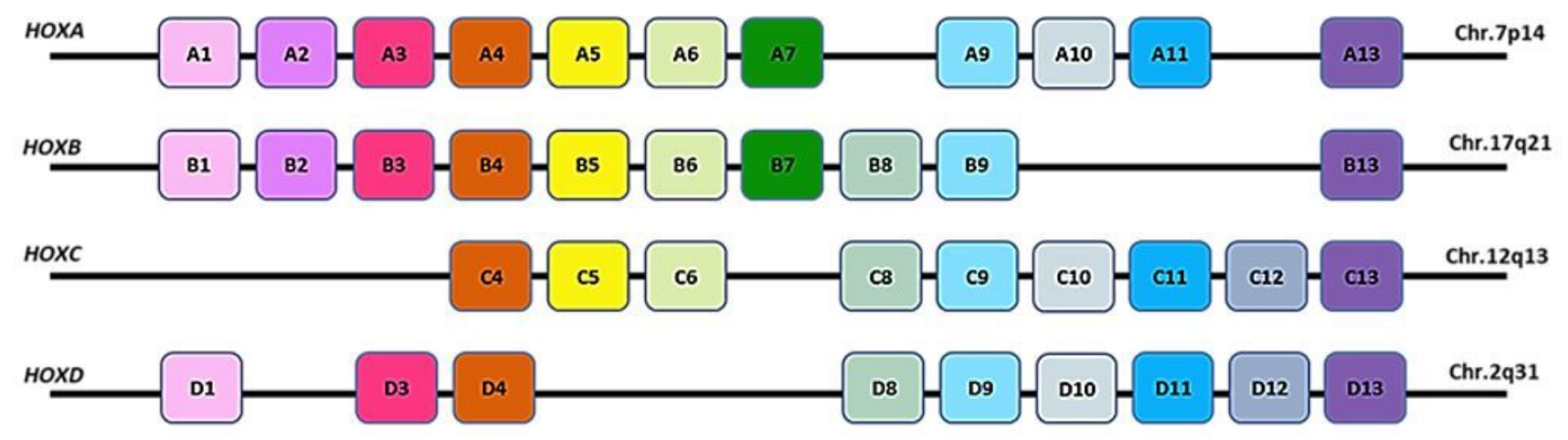

Anterior axis

Posterior axis

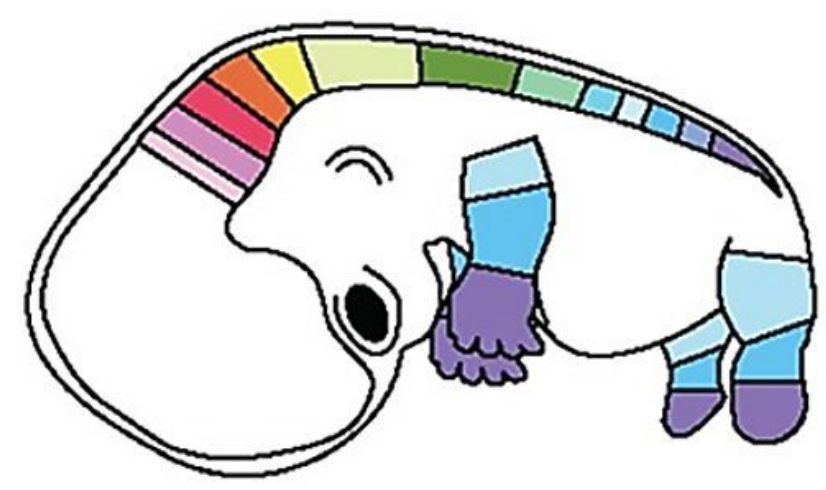

Figure 1

HOX genes in human genome Adapted from Durston et al. (8) The colour coding represents the correspondence between the genomic order of each HOX gene in the chromosomal cluster with the segmental identity in human embryo, (Microsoft PowerPoint software was used to create this figure) 


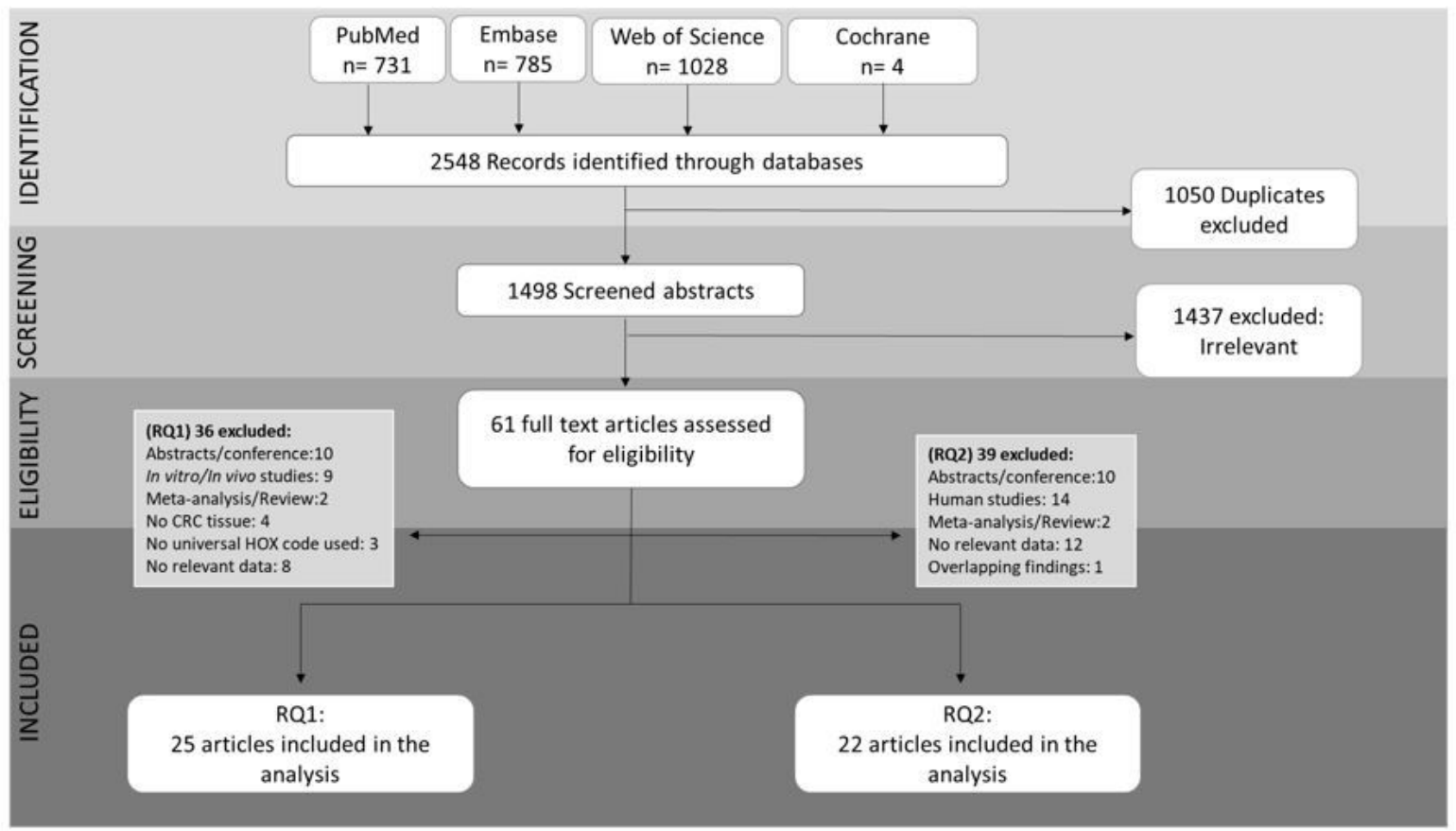

\section{Figure 2}

PRISMA flow chart of systematic review article retrieval (Microsoft PowerPoint software was used to create this figure)

\section{Supplementary Files}

This is a list of supplementary files associated with this preprint. Click to download.

- PRISMA2020checklistBMCMartinou.docx

- ESM1.docx

- Tables1ESM2.xlsx

- Tables2ESM3.xIsx 